\title{
METAKAOLINITE: Si \& Al PRECURSORS FOR KALSILITE SYNTHESIS
}

\author{
EDDY F. YUSSLEE*, NUR HAZWANI DAHON*, MOHD AZRUL ABD RAJAK*, "SAZMAL E. ARSHAD** \\ *Preparatory Centre For Science and Technology, Universiti Malaysia Sabah, 88400 Kota Kinabalu, Malaysia \\ **Faculty of Science and Natural Resources, Universiti Malaysia Sabah, 88400 Kota Kinabalu, Malaysia \\ "E-mail: sazmal@ums.edu.my
}

Submitted July 9, 2021; accepted September 17, 2021

\begin{abstract}
Keywords: Hydrothermal, Zeolite F, Kaolinite, Crystals, Diffraction
Metakaolinite has been used as a silica and alumina precursor to synthesise kalsilite via the hydrothermal method with the addition of potassium hydroxide $(\mathrm{KOH})$ as the potassium source. The effects of the $\mathrm{KOH}$ concentrations and reaction temperatures have been investigated. X-ray diffraction (XRD) diffractograms and field emission scanning electron microscope (FESEM) images showed the formation of hexagonal kalsilite after the hydrothermal reaction of metakaolinite at $190{ }^{\circ} \mathrm{C}$ in $1.25 \mathrm{M} \mathrm{KOH}$ for 24 hours. Kalsilite formed as a minor crystalline phase at a $\mathrm{KOH}$ concentration of less than $1.0 \mathrm{M} \mathrm{KOH}$, while, at a higher $\mathrm{KOH}$ concentration, the crystallinity of the product increases. On the other hand, $190{ }^{\circ} \mathrm{C}$ was sufficient to convert metakaolinite to kalsilite. Besides, zeolite $F$ and muscovite have been found as the dominant products at a lower $\mathrm{KOH}$ concentration and temperature, respectively.
\end{abstract}

\section{INTRODUCTION}

Kaolin is a product commonly used in the manufacture of ceramics, catalysts, cement production, and in agriculture. It is also important for the paper, rubber and plastics industries. For certain applications, however, kaolin is converted into a metakaolinite form by calcining [1]. Kaolinite $\left(\mathrm{Al}_{2} \mathrm{O}_{3} \cdot 2 \mathrm{SiO}_{2} \cdot 2 \mathrm{H}_{2} \mathrm{O}\right)$, the principal kaolin mineral, is a 1:1 layered phyllosilicate made of one tetrahedral sheet of silica and one octahedral sheet of alumina. There are smaller metal cations in the centre of the tetrahedrons and octahedrons and their apices are filled with oxygen atoms and groups of hydroxyls [2]. Thermal decomposition at $400{ }^{\circ} \mathrm{C}-700{ }^{\circ} \mathrm{C}$ disrupts kaolinite's crystalline structure. The heating reaction breaks off the mineral's -OH chain and the kaolinite structure collapses, resulting in metakaolinite $\left(\mathrm{Al}_{2} \mathrm{O}_{3} \cdot 2 \mathrm{SiO}_{2}\right)$, an amorphous aluminosilicate structure. Here, the coordination number of the $\mathrm{Al}$ changes from a single six $\left(\mathrm{Al}^{6}\right)$ to a mixture of five $\left(\mathrm{Al}^{5}\right)$ and four $\left(\mathrm{Al}^{4}\right)$ during the thermal decomposition reaction of kaolinite [3].

Several studies on the synthesis of kalsilite using kaolin as a precursor have been reported upon [4-7]. Kaolin was chosen due to its high silica and alumina contents, having a theoretical composition of $46.54 \%$ $\mathrm{SiO}_{2}, 39.5 \% \mathrm{Al}_{2} \mathrm{O}_{3}$ and $13.96 \%$ water [8]. Kalsilite,
$\mathrm{KAlSiO}_{4}$, is a type of basic mineral silicate and can be grouped into feldspathoids that typically co-exist with olivine, melilite, clinopyroxene, phlogopite, nepheline, and leucite, mainly formed in K-rich and silica undersaturated volcanic rocks [9]. Several methods are widely used to synthesise kalsilite from different types of Si and Al sources; however, hydrothermal $[10,11]$ and solid state [12] synthesis methods are economical and have relatively simple steps to produce pure materials with smaller particle sizes.

Despite its availability in nature, only several works in the literature report the conversion of kaolinite/metakaolinite to kalsilite, particularly using the hydrothermal synthesis procedure. Brachold and Aneziris [12] successfully synthesized kalsilite, to be used as anti-corrosion materials, from kaolin at $200{ }^{\circ} \mathrm{C}$ using the hydrothermal method. However, the report used high concentrations of potassium hydroxide $(\mathrm{KOH})$ $(50 \% \mathrm{w} / \mathrm{w})$, which involved increased manufacturing costs and could influence the environment unless it was systematically treated. The effects of $\mathrm{KOH}$ molarity and the synthesis temperatures toward the kalsilite formation from metakaolinite via the hydrothermal treatment was followed by the product characterisation using X-ray diffraction (XRD) and field emission scanning electron microscope (FESEM) and are described in the present research. 


\section{EXPERIMENTAL}

Materials and method

Kaolin from Sibelco Co. was used as the principal source for $\mathrm{Al}_{2} \mathrm{O}_{3}$ and $\mathrm{SiO}_{2}$ in all the synthesis sequences. Table 1 reflects the chemical composition of the kaolin. The additional source of $\mathrm{Al}_{2} \mathrm{O}_{3}$ comes from $\mathrm{Al}(\mathrm{OH})_{3}$ to achieve the desired ratio. Potassium hydroxide (Merck Ltd.) in the form of pellets and distilled water were used to prepare the alkali solution. The kaolin was calcined in a muffle furnace at $750{ }^{\circ} \mathrm{C}$ for the dihydroxylation and formed metakaolinite.

Table 1. Main chemical compositions of the kaolinite. Oxide content in wt. $\%$

\begin{tabular}{ccccccc}
\hline $\mathrm{Al}_{2} \mathrm{O}_{3}$ & $\mathrm{SiO}_{2}$ & $\mathrm{Fe}_{2} \mathrm{O}_{3}$ & $\mathrm{~K}_{2} \mathrm{O}$ & $\mathrm{TiO}_{2}$ & $\mathrm{MgO}$ & L.O.I \\
\hline 34.20 & 49.60 & 1.01 & 1.80 & 0.55 & 0.55 & 12.10 \\
\hline
\end{tabular}

$1.0 \mathrm{~g}$ metakaolinite was mixed with $100 \mathrm{ml}$ of various $\mathrm{KOH}$ solution concentrations from $0.50 \mathrm{M}$ to $1.25 \mathrm{M}$ in a stainless-steel hydrothermal reactor and heated from $170{ }^{\circ} \mathrm{C}$ up to $250{ }^{\circ} \mathrm{C}$ at $10^{\circ} \mathrm{C} \cdot \mathrm{min}^{-1}$ for $24 \mathrm{~h}$, respectively. The reactor's pressure was approximately equal to that of the water vapour pressure at the corresponding temperature. After cooling to room temperature, the products were filtered and washed repeatedly using distilled water and dried at $80{ }^{\circ} \mathrm{C}$ in an oven for $8 \mathrm{~h}$.

\section{Characterisation}

The XRD diffractograms of the untreated kaolin and synthesis products were analysed using a Rigaku Smartlab X-ray diffractometer model, $\mathrm{CuK} \alpha=1.54056$, $50 \mathrm{~mA}, 40 \mathrm{kV}$. The data collection was carried out in the range of $2 \theta: 5-80^{\circ}$, with a step size of $0.01^{\circ}$ under $\mathrm{Cu}$ $\mathrm{K} \alpha=1.54056,50 \mathrm{~mA}$ and $40 \mathrm{kV}$. The phase identification was performed by searching the International Centre for Diffraction Data (ICDD) powder diffraction file database, with the help of JCPDS (Joint Committee on Powder Diffraction Standards) files for inorganic compounds. The relative intensity yields were obtained from the normalised XRD intensities of the major reflection for each material. The average crystallite size, $D$, was determined using Scherrer's formula.

The solid phase morphologies were examined by a JEOL JSM-7900F FESEM, where the samples were coated with platinum. The samples were coated with a platinum layer to avoid charging effects from the free electrons and allowed for a clear image to be obtained. An inert element, such as platinum $(\mathrm{Pt})$, will discharge the free electrons liberated from the electron beam's bombardment on the sample's surface. The coated samples were observed using the FESEM under a $5000 \times$ to $50000 \times$ magnification.

\section{RESULTS AND DISCUSSION}

The dehydroxylation of kaolin to form metakaolinite, which has an amorphous aluminosilicate structure, is based on the following reaction:

$$
\mathrm{Al}_{2} \mathrm{Si}_{2} \mathrm{O}_{5}(\mathrm{OH})_{4} \rightarrow \mathrm{Al}_{2} \mathrm{Si}_{2} \mathrm{O}_{7}+2 \mathrm{H}_{2} \mathrm{O}
$$

$$
\text { The effect of } \mathrm{KOH} \text { molarity }
$$

The formation of kalsilite using metakaolinite as the $\mathrm{Si}$ and $\mathrm{Al}$ source in the $\mathrm{KOH}$ solution can be presented by the reaction:

$$
\mathrm{Al}_{2} \mathrm{Si}_{2} \mathrm{O}_{7}+2 \mathrm{KOH} \rightarrow 2 \mathrm{KAlSiO}_{4}+\mathrm{H}_{2} \mathrm{O}
$$

By referring to the stoichiometry above, $2 \mathrm{~mol}$ of kalsilite are formed from $1 \mathrm{~mol}$ of metakaolinite and $2 \mathrm{~mol} \mathrm{KOH}$. A similar trend can be seen when kaolin is used as the $\mathrm{Si}$ and $\mathrm{Al}$ precursor with the addition of $\mathrm{KOH}$ as the $\mathrm{K}^{+}$source, according to the equation below:

$$
\mathrm{Al}_{2} \mathrm{Si}_{2} \mathrm{O}_{5}(\mathrm{OH})_{4}+2 \mathrm{KOH} \rightarrow 2 \mathrm{KAlSiO}_{4}+3 \mathrm{H}_{2} \mathrm{O}
$$

Figure 1 shows the XRD diffractograms when metakaolinite is added with various $\mathrm{KOH}$ concentrations for the kalsilite formation.

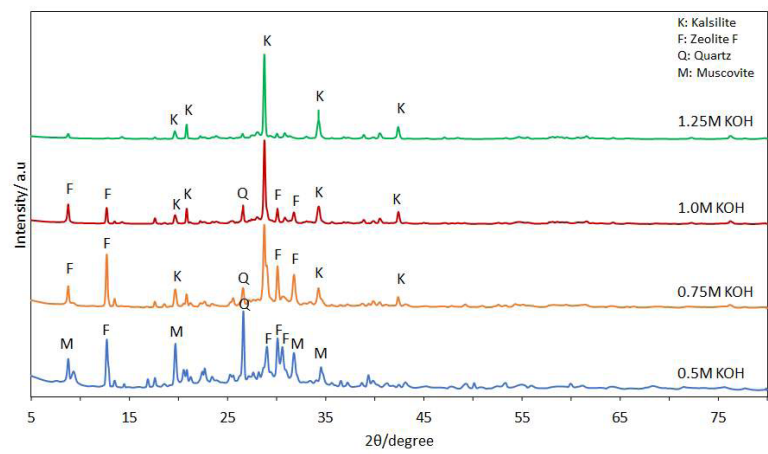

Figure 1. XRD diffractograms of the hydrothermal reaction products obtained at various $\mathrm{KOH}$ concentrations using metakaolinite as the precursor at $190{ }^{\circ} \mathrm{C}$.

The ICDD database PDF4+ 2020 was used for the phase identification. From the figure above, $1.25 \mathrm{M} \mathrm{KOH}$ shows the most significant kalsilite peaks (PDF file 00011-0579) at $20.8^{\circ}$ [002], $28.7^{\circ}$ [102], 34.2 ${ }^{\circ}$ [110] and $42.3^{\circ}$ [004]. A higher $\mathrm{KOH}$ concentration is required to produce highly crystalline kalsilite due to the $\mathrm{Si}$ and $\mathrm{Al}$ availability in the reaction media to bind with the $\mathrm{K}^{+}$ ions in the nucleation process and subsequently lead to the growth of the $\mathrm{KAlSiO}_{4}$ crystal. The argument is consistent with the findings of [13] after the researchers used a $\mathrm{KOH}$ concentration higher than 4.3 $\mathrm{M}$ when synthesising kalsilite using microcline as a precursor under hydrothermal conditions. Analogous results are also achieved by [14] when they used $4 \mathrm{M} \mathrm{KOH}$ added with an $\mathrm{SiO}_{2}$ powder and $\mathrm{Al}\left(\mathrm{NO}_{3}\right)_{3}$ to obtain $\mathrm{KAlSiO}_{4}$ 
after 336 hours using the hydrothermal reaction method. Compared with the above literature sources, this study shows metakaolinite can also be used as a precursor for the kalsilite synthesis under the hydrothermal reaction since it contains a high $\mathrm{Si}$ and $\mathrm{Al}$ composition with the Si:Al ratio close to 1 . Moreover, this work utilised a much lower $\mathrm{KOH}$ molarity, lowering the manufacturing cost and appealing to the ecosystem protection.

On the other hand, a further reduction in the $\mathrm{KOH}$ concentration promotes several diffraction peaks corresponding to zeolite $\mathrm{F}$, quartz and muscovite. It can be seen that the kalsilite crystal starts to form as a minor crystalline phase when $0.75 \mathrm{M} \mathrm{KOH}$ is used in the hydrothermal reaction while the main crystalline phase is zeolite F. The formation of zeolite $\mathrm{F}$ is in agreement with our expectations since its chemical formula is almost identical with kalsilite except with addition of a hydrated molecule $\left(\mathrm{KAlSiO}_{4} \cdot 1.5 \mathrm{H}_{2} \mathrm{O}\right)$ [15]. Based on the formula, the ratio of Si:Al is 1 and identical with the Si:Al ratio of kalsilite, hence providing the competition during the nucleation process as can be seen from the diffractograms when $0.75 \mathrm{M} \mathrm{KOH}$ and $1.0 \mathrm{M}$ $\mathrm{KOH}$ were used, respectively. Besides, no kalsilite is formed at a concentration below $0.5 \mathrm{M}$. The existence of the muscovite and quartz peaks in the diffractograms suggests that the dissolution of $\mathrm{Si}$ and $\mathrm{Al}$ in metakaolin occurs ineffectively due to the lack of $\mathrm{K}^{+}$ions, leading to the recrystallisation of the precursor.

\section{Effect of the reaction temperature}

The XRD patterns of the products obtained after the hydrothermal treatment of metakaolinite in the $1.25 \mathrm{M} \mathrm{KOH}$ solution at various temperatures are shown in Figure 2. A sample of the product synthesised at $170{ }^{\circ} \mathrm{C}$ only presents the diffraction peaks of muscovite, quartz and zeolite $\mathrm{F}$ as the major phases, indicating that metakaolinite failed to incorporate the $\mathrm{K}^{+}$ion available effectively at the accurate $\mathrm{Si}$ and $\mathrm{Al}$ ratio. The formation of muscovite (potassium aluminium silicate hydroxide) occurred due to the precipitation of alumina and silica from metakaolinite with $\mathrm{KOH}$ [16]. However, after

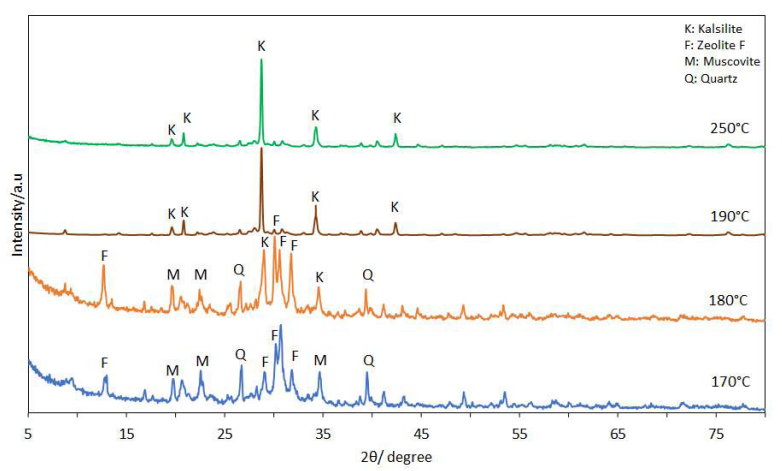

Figure 2. XRD diffractograms of the hydrothermal reaction products obtained at various temperature using metakaolinite as a precursor and $1.25 \mathrm{M} \mathrm{KOH}$. heating the sample at $180{ }^{\circ} \mathrm{C}$, two new peaks at $28.7^{\circ}$ [102] and $34.2^{\circ}$ [110], in addition to the diffraction peaks of the other major crystalline phases, are observed. These new peaks belong to $\mathrm{KAlSiO}_{4}\left(\mathrm{P}_{3}\right.$ space group, $\mathrm{PDF}$ file 00-011-0579). Figure 5 shows the crystal structure of the $\mathrm{P}_{3}$ space group kalsilite formed in this study modified from [17]. Each tetrahedron is connected with three $\mathrm{O}$ atoms in the plane perpendicular and by one $\mathrm{O}$ atom in the direction parallel to the c-axis, respectively. The hexagonal cell dimensions are $\mathrm{a}=5.23 \AA$ and $\mathrm{c}=8.55 \AA$.

The muscovite and quartz diffraction peaks gradually became weaker with each subsequent increase in temperature and disappear completely when the synthesis is carried out at $190{ }^{\circ} \mathrm{C}$, most probably due to the topotactic reaction between the $\mathrm{Si}$ and $\mathrm{Al}$ successfully incorporating the $\mathrm{K}^{+}$ion to form $\mathrm{KAlSiO}_{4}$ crystals. Further heating up to $250{ }^{\circ} \mathrm{C}$ of the sample shows identical $\mathrm{KAlSiO}_{4}$ peaks and the unit cell parameters for the crystal are $\mathrm{a}=5.23299$ and $\mathrm{c}=8.55349$, which are slightly larger than those reported by [18].

\section{Crystallite size}

The average crystallite size calculated by the Scherrer equation is shown below:

$$
D=\frac{K \lambda}{\beta \cos \theta}
$$

Where $D$ is the crystallite size, $K$ is a constant, $\lambda$ is the $\mathrm{X}$-ray wavelength, $\beta$ is the peak width at half of its height (FWHM) and $\theta$ is the scattering angle. The average crystallite size of $\mathrm{KAlSiO}_{4}$ is $220 \mathrm{~nm}$. The theoretical result is line with the FESEM images showing an average particle size of the crystal around $250 \mathrm{~nm}$. Comparing the results with Kimura et al. [19], a slightly bigger crystallite size is obtained in this study compared to the $100 \mathrm{~nm}$ crystal size reported by the researchers after the thermal treatment of nano-sodalite with $\mathrm{K}_{2} \mathrm{CO}_{3}$.

\section{FESEM morphologies}

The morphological characterisations of the synthesised products with the effect of the $\mathrm{KOH}$ concentrations and reaction temperatures are illustrated in Figure 3 and 4, respectively.

Figure 3a shows square pillars-like shaped crystals corresponding to zeolite $\mathrm{F}$ when the metakaolinite was treated with $0.75 \mathrm{M} \mathrm{KOH}$ while Figure $3 \mathrm{~b}$ shows hexagonal kalsilite crystals after $1.25 \mathrm{M} \mathrm{KOH}$ was used. Figure 4 presents the effect of the reaction temperatures on the product morphologies. Square pillar-like shaped crystals of zeolite F (Figure 4a) were observed when the reaction was carried out at the temperature $180{ }^{\circ} \mathrm{C}$. On the other hand, by further heating to $250^{\circ} \mathrm{C}$ resulted in hexagonal crystals corresponding to the kalsilite formation (Figure 4b). 


\section{CONCLUSIONS}

In this work, kalsilite was successfully synthesised using metakaolinite and $\mathrm{KOH}$ as precursors via the hydrothermal method while the effect of the $\mathrm{KOH}$ concentrations and reaction temperatures towards the crystal formation have been studied. Metakaolinite transforms into kalsilite when treated with $1.25 \mathrm{M}$ of $\mathrm{KOH}$ in a hydrothermal reaction at $190{ }^{\circ} \mathrm{C}$ for 24 hours. The average crystallite size of the formed $\mathrm{KAlSiO}_{4}$ was $220 \mathrm{~nm}$ after being calculated by using Scherrer's equation. Higher $\mathrm{KOH}$ concentrations increase the product's crystallinity while, at lower $\mathrm{KOH}$ concentrations, zeolite $\mathrm{F}$ and muscovite were obtained as the dominant products. A lower reaction temperature, up until $180{ }^{\circ} \mathrm{C}$, is not favourable for the kalsilite formation, instead, square pillar-like shapes of zeolite $\mathrm{F}$ and muscovite are formed. On the other hand, $190{ }^{\circ} \mathrm{C}$ was seen as adequate to fully transform metakaolinite to hexagonal kalsilite and is supported by the XRD and FESEM results.

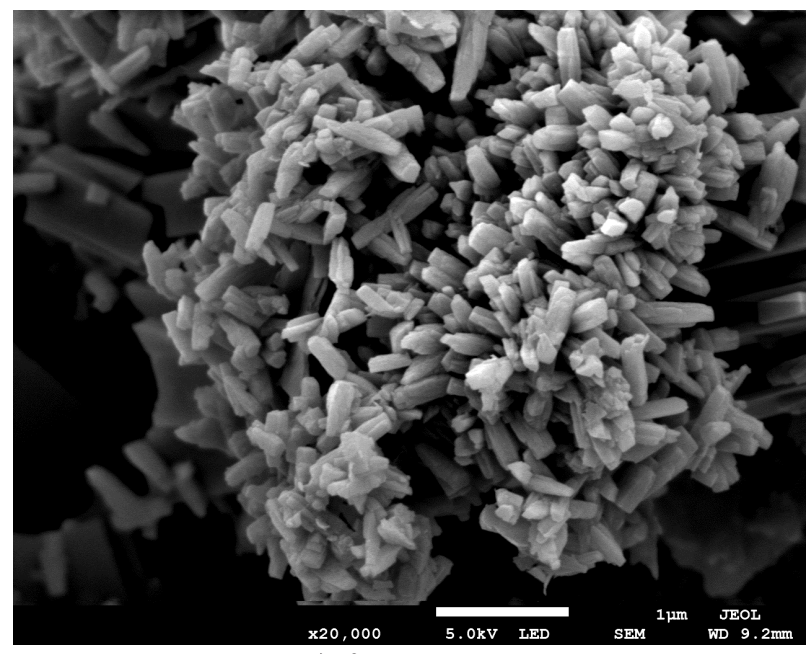

a) $0.75 \mathrm{M} \mathrm{KOH}$

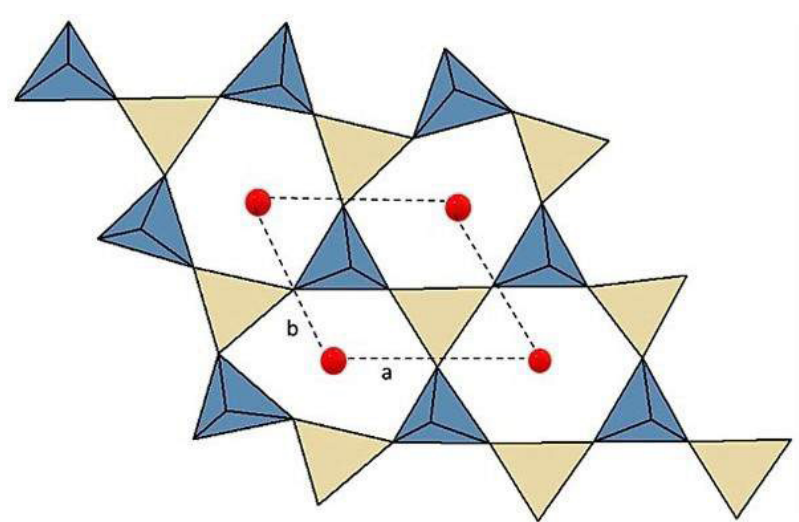

Figure 5. The crystal structure of the $\mathrm{P} 6_{3}$ kalsilite view along the c-axis. The red balls are $\mathrm{K}$ atoms, the Si-centred tetrahedra pointing downward (D) are brown, while the Al-centred tetrahedra pointing upward (U) are blue (modified from [20]).

Figure 3. FESEM images of the products formed after being treated at $190^{\circ} \mathrm{C}$.

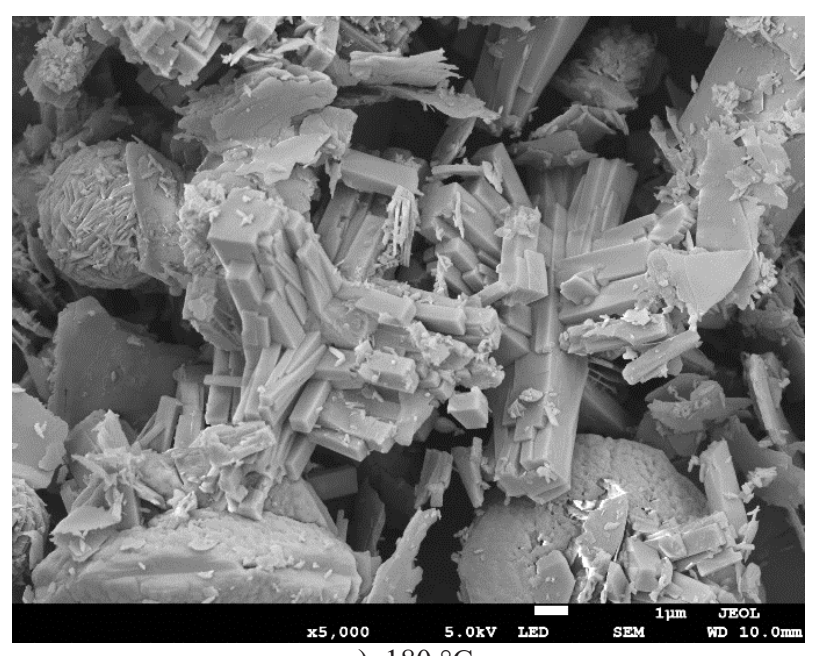

a) $180{ }^{\circ} \mathrm{C}$

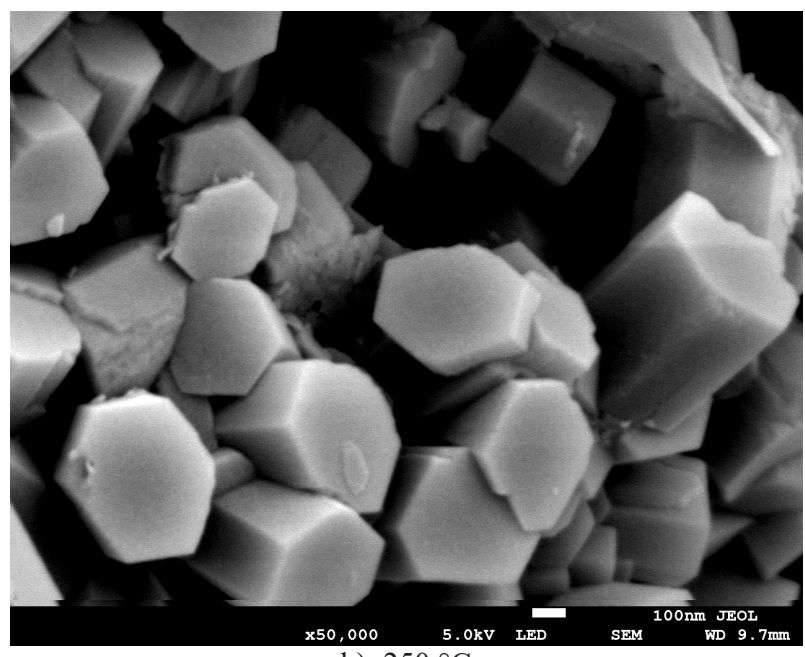

b) $250{ }^{\circ} \mathrm{C}$

Figure 4. FESEM images of the products formed at different temperatures after being treated with $1.25 \mathrm{M} \mathrm{KOH}$. 
Acknowledgment

The authors gratefully acknowledge and appreciate the financial support from the Universiti Malaysia Sabah, Malaysia (SBK0412-2018 \& GUG0248-2018).

\section{REFERENCE:}

[1] Arshad S. E., Rahman M. L., Sarkar S. M., Yusslee E. F., Patuwan, S. Z. (2018): Hydrothermal synthesis of zeolite $\mathrm{T}$ from kaolin using two different structure-directing agents. Materials Research Express, 5(1), 015011. doi:10.1088/2053-1591/aa9d05

[2] Ondro T., Trník A. (2018): Kinetic behaviour of thermal transformations of kaolinite. AIP Conference Proceedings, 1988. doi:10.1063/1.5047627

[3] Yuan W., Kuang J., Yu M., Huang Z. (2019): Effect of $\mathrm{Er}\left(\mathrm{NO}_{3}\right)_{3}$ on thermal activation of kaolinite and alkaline reaction behavior of metakaolin. Powder Technology, 354(3), 727-733. doi:10.1016/j.powtec.2019.06.042

[4] Becerro A. I., Escudero A., Mantovani M. (2009): The hydrothermal conversion of kaolinite to kalsilite: Influence of time, temperature, and $\mathrm{pH}$. American Mineralogist, 94(11-12), 1672-1678. doi:10.2138/am.2009.3284

[5] Becerro A. I., Mantovani M., Escudero A. (2009): Hydrothermal Synthesis of Kalsilite: A Simple and Economical Method. Journal of the American Ceramic Society, 92(10), 2204-2206. doi:10.1111/j.1551-2916.2009.03232.x

[6] Reyes C. A. R., Williams C. D. (2010): Hydrothermal transformation of kaolinite in the system $\mathrm{K}_{2} \mathrm{O}-\mathrm{SiO}_{2}-\mathrm{Al}_{2} \mathrm{O}_{3}$ $\mathrm{H}_{2} \mathrm{O}$. DYNA (Colombia), 77(163), 55-63.

[7] Wu Y., Wu X., Tu B. (2017): Phase relations of the nepheline-kalsilite system: X-ray diffraction and Mössbauer spectroscopy. Journal of Alloys and Compounds, 712, 613617. doi:10.1016/j.jallcom.2017.04.164

[8] Irfan Khan M., Khan H. U., Azizli K., Sufian S., Man Z., Siyal A. A., et al. (2017): The pyrolysis kinetics of the conversion of Malaysian kaolin to metakaolin. Applied Clay Science, 146, 152-161. doi:10.1016/j.clay.2017.05.017

[9] Gatta G. D., Angel R. J., Zhao J., Alvaro M., Rotiroti N., Carpenter M. A. (2011): Phase stability, elastic behavior, and pressure-induced structural evolution of kalsilite: A ceramic material and high-T/high-P mineral. American Mineralogist, 96(8-9), 1363-1372. doi:10.2138/ am.2011.3793

[10] Novembre D., Gimeno D., d'Alessandro N., Tonucci L. (2018): Hydrothermal synthesis and characterization of kalsilite by using a kaolinitic rock from Sardinia,
Italy, and its application in the production of biodiesel. Mineralogical Magazine, 82(4), 961-973. doi:10.1180/ minmag.2017.081.080

[11] Yusslee E. F., Dahon N. H., Azrul M., Rajak A., Arshad S. E. (2021): Transformation of Kaolin to Kalsilite : Effect of $\mathrm{KOH}$ Concentration and Reaction Temperature. Malaysian Journal of Chemistry, 23(2), 115-120.

[12] Brachhold N., Aneziris C. G. (2013): Porous materials for alkali contaminated environments. Journal of the European Ceramic Society, 33(10), 2013-2021. doi:10.1016/j. jeurceramsoc.2012.11.029

[13] Su S.Q., Ma H.W., Yang J., Zhang P., Luo Z. (2014): Synthesis of kalsilite from microcline powder by an alkalihydrothermal process. International Journal of Minerals, Metallurgy and Materials, 21(8), 826-831. doi:10.1007/ s12613-014-0977-7.

[14] Kakutani Y., Weerachawanasak P., Hirata Y., Sano M., Suzuki T., Miyake T. (2017): Highly effective K-Merlinoite adsorbent for removal of $\mathrm{Cs}^{+}$and $\mathrm{Sr}^{2+}$ in aqueous solution. RSC Adv., 7(49), 30919-30928. doi:10.1039/C7RA03867D

[15] Yuan J., Yang J., Ma H., Su S., Chang Q., Komarneni S. (2018): Hydrothermal synthesis of nano-kaolinite from K-feldspar. Ceramics International, 44(13), 15611-15617. doi:10.1016/j.ceramint.2018.05.227

[16] Sruthi P. L., Reddy P, H. P. (2017): Characterization of kaolinitic clays subjected to alkali contamination. Applied Clay Science, 146(April), 535-547. doi:10.1016/ j.clay.2017.07.012

[17] Yuan J., Ma H., Luo Z., Ma X., Guo Q. (2021): Synthesis of kalsio4 by hydrothermal processing on biotite syenite and dissolution reaction kinetics. Minerals, 11(1), 1-13. doi: $10.3390 / \min 11010036$

[18] Su S., Ma H., Yang J., Liu H., Li G. (2012): Synthesis and Characterization of kalsilite from Microcline powder. Journal of the Chinese Ceramic Society, 40(1), 145-148.

[19] Kimura R., Wakabayashi J., Elangovan S. P., Ogura M., Okubo T. (2008): Nepheline from $\mathrm{K}_{2} \mathrm{CO}_{3} /$ Nanosized sodalite as a prospective candidate for diesel soot combustion. Journal of American Chemical Society, 130, 12844-12845. doi:10.1021/ja802102q

[20] Cellai D., Gesing T. M., Wruck B., Carpenter M. A. (1999): X-ray study of the trigonal $\rightarrow$ hexagonal phase transition in metamorphic kalsilite. American Mineralogist, 84(11-12), 1950-1955. doi:10.2138/am-1999-11-1223 